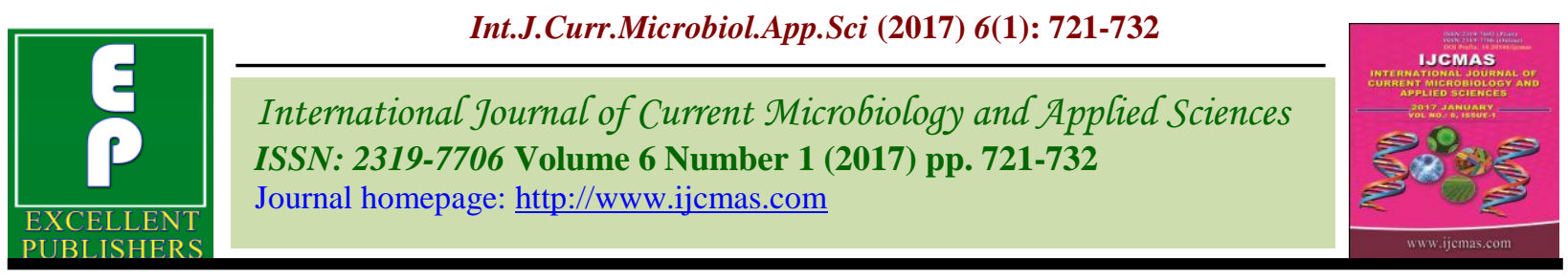

Original Research Article

http://dx.doi.org/10.20546/ijcmas.2017.601.086

\title{
Potency of Two Commonly Available Plants Pisonia alba and Mukia maderaspatana in the Health Industry
}

\author{
C. Vishnupriya* and Fauzia Ahmed \\ P.G and Research Department of Zoology, J.B.A.S College for women, \\ Chennai-600 116, Tamilnadu, India \\ *Corresponding author
}

\section{A B S T R A C T}

Keywords

Pisonia alba,

Mukia maderaspatana,

Phytochemical

screening,

Antioxidant,

Antimicrobial activity,

Zone of inhibition.

Article Info

Accepted:

29 December 2016

Available Online:

10 January 2017
Pisonia alba commonly known as Leechikottaikerai in tamil is a widely used plant. In the alternative system of medicine Pisonia alba leaves are used as anti-inflammatory, antidiuretic and antifungal. Mukia maderaspatana is an important traditional medicinal plant used generally in Western districts of Tamilnadu. It has properties like anti-rheumatic, antiflatulent and anticancer also. The present study was carried out to investigate the phytochemical screening, antioxidant and antimicrobial activity of aqueous and ethanolic extracts of the leaves of both the plants. The phytochemical analysis of the leaf extracts of Mukia maderaspatana and Pisonia alba revealed the presence of tannins, saponins, quinines, flavanoids, cardiac glycosides, phenolic acids, terpenoids, coumarins, steroids and betacyanins. The results showed that the phytochemical properties of the leaves have the potency of being used in the health industry. The strongest radical scavenging activity $(76.4 \%)$ was exhibited by the ethanolic extract of Pisonia alba, moderate activity $(59.8 \%)$ was recorded in ethanolic extract of Mukia masderaspatana and weakest activity(51.2\%) was exhibited by the aqueous extract of Pisonia alba followed by aqueous extract of Mukia maderaspatana $(46.4 \%)$. The zone of inhibition by disc diffusion method were measured for determining antimicrobial action of ethanolic extracts of Pisonia alba and Mukia maderaspatana leaves against Bacillus cereus, Bacillus subtilis, Escherichia coli, Pseudomonas aureginosa and Staphylococcus aureus. Among the various extracts, maximum antimicrobial activity was exhibited by ethanolic extract of Pisonia alba followed by ethanolic extract of Mukia maderaspatana.

\section{Introduction}

Plants, our gifts of nature which are the sources of bioactive constituents have been used traditionally to cure various ailments in Ayurvedha, Unani and Siddha. During last few years, synthetic drugs occupy the highest position for curing various disease due to their side effects, scientists are now focusing highest on exploring the potentiality of traditional medicines (Gopalakrishnan sasi priya et al., 2012).
As we move into the $21^{\text {st }}$ century, we observe a big change in the attitude of physicians, researchers and the general public towards prophylaxis and therapeutics originating from plant drugs. Nearly all-major pharmaceutical houses are back into research on plant product (Shah et al., 1986).

The plant Pisonia alba, belonging to the family Nyctaginaceae, is an evergreen 
glabrous garden tree with young shoots are minutely puberulous. In the alternative system of medicine Pisonia alba leaves are used as analgesic, anti-inflammatory, diuretic (Radha, et al., 2008), hypoglycemic agent (Sunil et $a l ., 2009$ ) and antifungal (Shubashini et al., 2010). It is also used in the treatment of ulcer, dysentery and snake bite. The leaves are edible and mostly used to treat wound healing, rheumatism and arthritis (Prabhu et al., 2008).

Mukia maderaspatana (L.) M.Roem. of the family, Cucurbitaceae is an important traditional medicinal plant generally practiced in western districts of Tamil Nadu. The species is mainly distributed in tropical regions of India, especially in the lower hills of the Western Ghats (Singh and Panda, 2005). The plant is bitter, sweet, refrigerant, carminative, vulnerary, expectorant and tonic and it is useful in vitiated conditions of pitta, burning sensation, dyspepsia, flatulence, colic, constipation, ulcers, cough, asthma and vertigo (Sowndhararajan et al., 2010). Further it is reported to have the properties viz., antirheumatic, anti-flatulent, anti-inflammatory, anticancer, anti-diabetic, diuretic and stomachic also. Sequeezed plant is applied to treat scabies of animals (Mallikadevi et al., 2012).

Photochemical are naturally occurring and biologically active plant compounds that have potential disease inhibiting capabilities. It is believed that photochemical may be effective in combating or preventing disease due to their antioxidant effect (Halliwell and Gutteridge, 1992). Photochemical are bioactive compounds found in plants that work with nutrients and dietary fiber to protect against diseases. They are nonnutritive compounds. These photochemical are the secondary metabolites present in smaller quantities in higher plants and they include the alkaloids, Steroids, flavonoids, terpenoids, tannins and many others (Peteros, 2010). Antioxidants are substances that may protect our body cells against the effects of free radicals. Free radicals are molecules produced when our body breaks down food (Padamanabhan vasanthi et al., 2014). Increasing the anti-oxidant intake can prevent diseases and lower health problems. Research is increasingly showing that antioxidant rich foods and herbs have health benefits. Medicinal herbs are the richest sources of antioxidants compounds (Sies et al., 1992). Natural antioxidants tend to be safer and also possess anti-viral, anti-inflammatory, anticancer, anti-mutagenic, antitumor and hepatoprotective properties (Baravalia et al., 2009).

The frequency of life-threatening infections caused by pathogenic microorganisms has increased worldwide and is becoming an important cause of morbidity and mortality in immune compromised patients in developing countries (Al-Bari et al., 2006). Plant materials remain an important resource to combat serious diseases in the world. The pharmacological investigations of plants were carried out to find novel drugs or templates for the development of new therapeutic agents (Iwu et al., 1999). These antimicrobial substances are of natural origin, and it is thought that their influences on the environment are few and can be used as biological control agents (Natarajan et al., 2010). The present study is aimed to evaluate the efficacy of the two plants namely Pisonia alba and Mukia maderaspatana as potent antioxidants and antimicrobial agents and also to investigates the phytochemical compounds.

\section{Materials and Methods}

\section{Collection and preparation of plant materials}

The leaves of Mukia maderaspatana and 
Pisonia alba were collected in local areas of Chennai city. The leaves of the plants Mukia maderaspatana and Pisonia alba were cleaned and shade dried. The dried leaves were crushed and sieved through mesh cloth to get fine powder.

Preparation of the extracts was done according to a combination of the methods used by (Janarthanam \& Sumathi, 2010). About 1g of dried leaf powder of Mukia maderaspatana and Pisonia alba plant materials were extracted with $20 \mathrm{ml}$ ethanol (75\%) and aqueous for 1 minute using an Ultra Turax mixer $(13,000 \mathrm{rpm})$ and soaked overnight at room temperature. The sample was then filtered through Whatman No. 1 paper in a Buchner funnel. The filtered solution was evaporated under vacuum in a rota-evator at $40^{\circ} \mathrm{C}$ to a constant weight and then dissolved in ethanol and water. The dissolving rate of the crude extracts was approximately $100 \%$. The solution was stored at $18^{\circ} \mathrm{C}$ until use.

\section{Phytochemical Screening of the Leaf Extracts}

The phytochemical screening of leaf extracts were assessed by standard method as described by (Savithramma et al., 2011; Selvaraj et al., 2014).

Phytochemical screening was carried out on the leaf extracts using different solvents to identify the major natural chemical groups such as tannins, saponins, flavonoids, phenols, terpenoids, alkaloids, glycosides, cardiac glycosides, coumarins, quinines, steroids and beta cyanin. General reactions in these analyses revealed the presence or absence of these compounds in the leaf extracts tested.

\section{Test for Tannins}

For identification of tannins, $1 \mathrm{ml}$ of the plant extract, $1 \mathrm{ml}$ of ferric chloride $\left(5 \% \mathrm{FeCl}_{3}\right)$ was added. Formation of dark blue or greenish black indicates the presence of tannins.

\section{Test for Saponins}

For identification of saponins, $2 \mathrm{ml}$ Plant extract, $2 \mathrm{ml}$ of distilled water was added and shaken in graduated cylinder for $15 \mathrm{~min}$ lengthwise, formation of $1 \mathrm{~cm}$ layer of foam indicates the presence of saponins.

\section{Test for Quinones}

For identification of quinones, $1 \mathrm{ml}$ Plant extract, $1 \mathrm{ml}$ of concentrated sulphuric acid $\left(\mathrm{H}_{2} \mathrm{SO}_{4}\right)$ was added. Formation of red colour indicates the presence of Quinones.

\section{Test for Flavonoids}

For identification of flavonoids, $2 \mathrm{ml}$ of plant extract, $1 \mathrm{ml}$ of $2 \mathrm{~N}$ sodium hydroxide $(\mathrm{NaOH})$ was added. Formation of yellow colour indicates the presence of flavonoids.

\section{Test for Alkaloids}

For identification of alkaloids, $2 \mathrm{ml}$ Plant extract, $2 \mathrm{ml}$ of concentrated Hydrochloric acid $(\mathrm{HCl})$ was added. Then few drops Mayer's reagent was added. Presence of green colour or white precipitate indicates the presence of alkaloids.

\section{Test for Glycosides}

For identification of glycosides, $2 \mathrm{ml}$ of the plant extract, $3 \mathrm{ml}$ of chloroform and $10 \%$ ammonium solution was added. Formation of pink colour indicates the presence of glycosides.

\section{Test for Cardiac Glycosides}

For identification of Cardiac glycosides, 0.5 
$\mathrm{ml}$ of the plant extract, $2 \mathrm{ml}$ of glacial acetic acid and few drops of $5 \%$ ferric chloride were added. This was under layered with $1 \mathrm{ml}$ of concentrated sulphuric acid. Formation of brown ring at interface indicates the presence of cardiac glycosides.

\section{Test for Terpenoids}

For identification of terpenoids, $0.5 \mathrm{ml}$ of the plant extract, $2 \mathrm{ml}$ of chloroform along with concentrated Sulphuric acid. Formation of red brown colour at the interface indicates the presence of Terpenoids.

\section{Test for Phenols}

For identification of phenols, $1 \mathrm{ml}$ of the plant extract, $2 \mathrm{ml}$ of distilled water followed by few drops of $10 \%$ ferric chloride was added. Formation of blue / green colour indicates the presence of phenols.

\section{Test for Steroids}

For identification of steroids, $0.5 \mathrm{ml}$ of the plant extract, $2 \mathrm{ml}$ of chloroform and $1 \mathrm{ml}$ of Sulphuric acid $\left(\mathrm{H}_{2} \quad \mathrm{SO}_{4}\right)$ were added. Formation of reddish brown ring at interface indicates the presence of steroids.

\section{Test for Coumarins}

For identification of coumarins, $1 \mathrm{ml}$ of plant extract, $1 \mathrm{ml}$ of $10 \% \mathrm{NaOH}$ was added. Formation of yellow colour indicates the presence of coumarins.

\section{Test for Betacyanin}

For identification of betacyanin, $2 \mathrm{ml}$ of the plant extract, one $\mathrm{ml}$ of $2 \mathrm{~N}$ sodium hydroxide $(\mathrm{NaOH})$ was added and heated for $5 \mathrm{~min}$ at $100^{\circ} \mathrm{C}$. Formation of yellow colour indicates the presence of betacyanin.

\section{Antioxidant Activity}

\section{Qualitative Analysis of Antioxidant Activity}

The antioxidant activity of leaf extracts of Mukia maderaspatana and Pisonia alba was determined by following the method as described by (George et al., 1996; Samundeeswari \& Chittibabu, 2013). 50 $\mu \mathrm{L}$ of leaf extracts of the two plants were taken in the microtiter plate. $100 \mu \mathrm{L}$ of $0.1 \%$ methanolic DPPH was added over the samples and incubated for 30 minutes in dark condition. The samples were then observed for discoloration; from purple to yellow and pale pink were considered as strong and weak positive respectively. The antioxidant positive samples were subjected for further quantitative analysis.

\section{Quantitative Analysis of Free Radical Scavenging Activity}

The antioxidant activities were determined using DPPH, (Sigma-Aldrich) as a free radical. Leaf extract of $100 \mu$ were mixed with $2.7 \mathrm{ml}$ of methanol and then $200 \mu \mathrm{l}$ of 0.1 $\%$ methanolic DPPH was added. The suspension was incubated for 30 minutes in dark condition. Initially, absorption of blank sample containing the same amount of methanol and DPPH solution was prepared and measured as a control (Lee et al., 2003). Subsequently, at every $5 \mathrm{~min}$ interval, the absorption maxima of the solution were measured using a UV double beam spectra scan (Chemito, India) at $517 \mathrm{~nm}$.

Free radical scavenging activity was calculated by the following formula:

$\%$ DPPH radical-scavenging $=($ Absorbance of control - Absorbance of test Sample $) \times 100$

(Absorbance of control) 
The antioxidant activity of the sample was compared with known synthetic standard of $(0.16 \%)$ of Butylated Hydroxy Toluene (BHT). The experiment was carried out in triplicate.

\section{Antibacterial Activity of Leaf Extracts}

The leaf extracts of Mukia maderaspatana and Pisonia alba plants were used for antibacterial study (Janarthanam \& Sumathi, 2010; Ozkan et al., 2004). Different concentration $(50,100$ and $150 \mathrm{mg} / \mathrm{ml})$ of the concentrated leaf extracts was tested for its antibacterial activity against Bacillus cereus, Bacillus subtilis, Escherichia coli, Pseudomonas aeruginosa and Staphylococcus aureus. The bacterial cultures were grown in Muller Hinton Agar and Muller Hinton broth (Himedia) (Lopez et al., 2001).

Antibacterial activity was measured using the standard method of diffusion disc plates on agar (Ertuk et al., 2006). Then $0.1 \mathrm{ml}$ of each culture of bacteria was spread on agar plate surfaces. For antibacterial assay, all bacterial strains were grown in Muller Hinton Broth Medium (Hi media) for 24 hours at $37^{\circ} \mathrm{C}$ and plated on Muller Hinton Agar (Hi media) for agar diffusion experiments. Paper disc $(6 \mathrm{~mm}$ in diameter) were placed on the agar medium to load $10 \mu 1,20 \mu 1$ and $30 \mu 1$ of different concentrations of leaf extracts of Mukia maderaspatana and Pisonia alba were tested. Zone of Inhibition diameters were measured after incubation for $24-48$ hours at $37^{\circ} \mathrm{C}$.

\section{Results and Discussion}

\section{Phytochemical screening}

Phytochemical screening of the leaf extracts of Pisonia alba \& Mukia maderaspatana revealed the presence of different kind of chemical groups that are summarized in table. 1. Aqueous and ethanolic extracts of leaves of Pisonia alba contain tannins, saponins, flavanoids, phenolic acids, terpenoids, coumarins, steroids, betacyanin. Aqueous and ethanolic extract of leaves of Mukia maderaspatana contain tannins, saponins, quinones, flavanoids, cardiac glycosides, phenolic acids, terpenoids, coumarins, steroids, betacyanins. All the tested extracts failed to detect alkaloids and glycosides.

The Medicinal plants are rich in secondary metabolites which include alkaloids, flavonoids, steroids and related active metabolites which are of great medicinal value and have been extensively used in the drug and pharmaceutical industry. Recently number of studies had been reported on the phytochemistry of medicinal plants, particularly on the vegetative parts like leaves and stems etc (Balakumar et al., 2011; Paulraj et al., 2011; Kala et al., 2011).

Saponins are generally regarded as antinutrients but are also believed to be useful in human diet for controlling cholesterols. Its presence in this plant therefore could suggest that the plant is of medicinal value. There is evidence of the presence of saponins in the traditional medicine preparations (Asl \& Hosseinzade, 2008; Xu et al., 1996).

Among the observed phytoconstitents saponins and phenolic acids are abundantly present in all the tested extracts of leaves when compared to other chemicals. These phytochemical compounds are known to support bioactive activities in medicinal plants and thus responsible for the antioxidant activities of this plant extract used in this study it also reveal that the plant contains bioactive compounds which are connected with antimicrobial activity of plants.

\section{Antioxidant assay}

Among the leaf extracts of Pisonia alba and Mukia maderaspatana, Ethanolic extracts was found to have positive antioxidant activity, 
whereas their Aqueous extract had semipositive antioxidant activity. The results of the free radical scavenging activity of the 1,1diphenyl - 2 picryl - hydrazyl (DPPH) assay showed percentage antioxidant activity (\%AA) is $76.4 \%$ in ethanolic leaf extract of Pisonia alba followed by its Aqueous extract with $51.2 \%$ of Antioxidant activity. In Mukia maderaspatana, the free radical scavenging activity was highest in ethanolic extract with $59.8 \%$, followed by its aqueous extract with $46.4 \%$ which is summarized in table. $2 \&$ fig. 1. Ethanol extract of Pisonia alba and Ethanol extract of Mukia maderaspatana was found to have highest antioxidant activity both qualitatively and quantitatively.

The Antioxidant shows an important Scavenging activity for free radicals of DPPH (1,1-Diphenyl-2-picryl hydrazyl) is widely used in pathogenesis of many diseases. The usage of synthetic antioxidant components may shows many side effects like toxicity and mutagenic effects, it made an alternative search of naturally occurring antioxidants (Saritha et al., 2014).

Different accessions of Pisonia alba and Mukia maderaspatana leaf samples were used for antioxidant studies. Analysis on different extraction of ethanol (75\%) and aqueous extract showed the presence of antioxidants. Among the two different solvent extracts of Pisonia alba and Mukia maderaspatana the ethanolic leaf extracts of both the plants recorded the most effective DPPH radical scavenging activity $(76.4 \%$ \& $59.8 \%)$ In each case, ethanolic leaf extracts recorded higher percentage of free radical scavenging activity than aqueous extract. These diverse groups of compounds have received much attention as potential natural antioxidant in terms of their ability to act as radical scavengers.

The Ethanolic extracts of Pisonia alba and Mukia maderaspatana showed good results, and was used further in testing their antimicrobial activity.

\section{Antimicrobial activity}

The zone of inhibition diameter of Ethanolic extract of Pisonia alba and Ethanolic extract of Mukia maderaspatana for laboratory strains Bacillus cereus, Bacillus subtilis, Escherichia coli, Pseudomonas aeruginosa, Staphylococcus aureus, is shown in table. $3 \&$ 4.

In the Ethanolic extract of Pisonia alba at the lower concentrations of $10 \mu \mathrm{l}$ the extract showed no antibacterial activity against Bacillus subtilis, Staphylococcus aureus, Escherichia coli, where as for Bacillus cereus and Pseudomonas aeruginosa showed antibacterial activity with $9 \mathrm{~mm}$ and $8 \mathrm{~mm}$ inhibition. At the concentration of $20 \mu 1$ the extract showed antibacterial activity for each bacterial strain of Bacillus cereus, Bacillus subtilis, Pseudomonas aeruginosa, Staphylococcus aureus $(10,10,10,8 \mathrm{~mm})$ except Escherichia coli. When the concentration was increased to $30 \mu 1$, the plant extract showed higher antibacterial activity with significant inhibition of bacteria. Significant zone of inhibition was observed in bacteria including Staphylococcus aureus and Bacillus cereus with maximum zone of inhibition being $13 \mathrm{~mm}$ and $19 \mathrm{~mm}$ respectively at the concentration of $30 \mu \mathrm{l}$ in Pisonia alba ethanol extract. Rest of the tested bacteria also had zone of inhibition though lesser than the other bacteria $(11,10,9 \mathrm{~mm})$.

Mukia maderaspatana ethanol extract was found to be not effective against bacterial strains Bacillus subtilis, Staphylococcus aureus and Escherichia coli at lower concentration of $10 \mu 1$, whereas for Bacillus cereus and Pseudomonas aeruginosa it showed antibacterial activity to some extent about $7 \mathrm{~mm}$ and $11 \mathrm{~mm}$. At the concentration of $20 \mu 1$ the plant extract showed antibacterial activity for all bacterial strains though with lesser zone of inhibition. When concentration 
was increased to $30 \mu 1$, the plant extract showed Significant zone of inhibition in bacteria Pseudomonas aeruginosa with maximum of $18 \mathrm{~mm}$ respectively. Rest of the bacteria Bacilus cereus (10mm), Bacillus subtilis(11mm), Escherichia coli( $9 \mathrm{~mm})$, Staphylococcus aureus $(11 \mathrm{~mm})$ also had zone of inhibition though lesser than Pseudomonas aeruginosa.

Table.1 Phytochemical Analysis of Pisonia alba and Mukia maderaspatana

\begin{tabular}{|l|c|c|c|c|}
\hline Constituent tests & $\begin{array}{c}\text { Aqueous } \\
\text { extract of } \\
\text { Pisonia alba }\end{array}$ & $\begin{array}{c}\text { Ethanolic } \\
\text { extract of } \\
\text { Pisonia alba }\end{array}$ & $\begin{array}{c}\text { Aqueous extract } \\
\text { of Mukia } \\
\text { maderaspatana }\end{array}$ & $\begin{array}{c}\text { Ethanolic } \\
\text { extract of Mukia } \\
\text { maderaspatana }\end{array}$ \\
\hline Tannins & + & + & + & + \\
\hline Saponins & ++ & ++ & + & ++ \\
\hline Quinones & - & - & + & + \\
\hline Flavanoids & ++ & ++ & - & - \\
\hline Alkaloids & - & - & - & - \\
\hline Glycosides & - & - & - & + \\
\hline Cardiac glycosides & - & - & ++ & + \\
\hline Phenolic acids & ++ & ++ & + & + \\
\hline Terpenoids & - & + & + & + \\
\hline Coumarins & ++ & ++ & + & + \\
\hline Steroids & + & + & + & + \\
\hline Beta cyanins & + & + & + & + \\
\hline
\end{tabular}

++ : Double Positive

+ : Positive

- : Negative

Table.2 DPPH free radical scavenging activity of Pisonia alba and Mukia maderaspatana

\begin{tabular}{|c|c|c|c|c|c|c|c|}
\hline Minutes & $\mathbf{0}$ & $\mathbf{5}$ & $\mathbf{1 0}$ & $\mathbf{1 5}$ & $\mathbf{2 0}$ & $\mathbf{2 5}$ & $\mathbf{3 0}$ \\
\hline $\begin{array}{c}\text { Pisonia- } \\
\text { Aqueous(\%) }\end{array}$ & 37.0 & 43.3 & 45.7 & 47.2 & 49.6 & 49.6 & 51.2 \\
\hline $\begin{array}{c}\text { Pisonia- } \\
\text { Ethanol(\%) }\end{array}$ & 72.4 & 76.4 & 76.4 & 76.4 & 76.4 & 76.4 & 76.4 \\
\hline $\begin{array}{c}\text { Mukia- } \\
\text { Aqueous(\%) }\end{array}$ & 37.0 & 40.9 & 44.1 & 44.9 & 45.7 & 45.7 & 46.4 \\
\hline Mukia-Ethanol(\%) & 41.7 & 51.9 & 52.7 & 59.8 & 59.8 & 59.8 & 59.8 \\
\hline BHT(standard)\% & 88.9 & 91.3 & 92.9 & 94.4 & 95.2 & 96.8 & 98.4 \\
\hline DPPH(control) & 1.27 & & & & & & \\
\hline
\end{tabular}


Table.3 Antibacterial activity in ethanolic extract of Pisonia alba against bacterial pathogens

\begin{tabular}{|c|c|c|c|}
\hline \multirow{2}{*}{$\begin{array}{c}\text { Name of the } \\
\text { Pathogenic } \\
\text { Bacteria }\end{array}$} & $\mathbf{1 0 \mu l}$ & $\mathbf{2 0 \mu l}$ & $\mathbf{3 0 \mu l}$ \\
\cline { 2 - 4 } & 9 & 10 & 19 \\
\hline Bacillus cereus & - & 10 & 9 \\
\hline Bacillus subtilis & - & - & 10 \\
\hline Escherichia coli & 8 & 10 & 11 \\
\hline $\begin{array}{c}\text { Pseudomonas } \\
\text { aeruginosa }\end{array}$ & - & 8 & 13 \\
\hline $\begin{array}{c}\text { Staphylococcus } \\
\text { aureus }\end{array}$ & & & \\
\hline
\end{tabular}

Table.4 Antibacterial Activity In Ethanolic Extract of Mukia maderaspatana Against Bacterial Pathogens

\begin{tabular}{|c|c|c|c|}
\hline \multirow{2}{*}{$\begin{array}{c}\text { Name of the } \\
\text { Pathogenic Bacteria }\end{array}$} & $\mathbf{1 0 \mu l}$ & $\mathbf{2 0 \mu l}$ & $\mathbf{3 0} \boldsymbol{\mu l}$ \\
\hline Bacillus cereus & 7 & 10 & 10 \\
\hline Bacillus subtilis & - & 9 & 11 \\
\hline Escherichia coli & - & 9 & 9 \\
\hline $\begin{array}{c}\text { Pseudomonas } \\
\text { aeruginosa }\end{array}$ & 11 & 15 & 18 \\
\hline Staphylococcus aureus & - & 9 & 11 \\
\hline
\end{tabular}

Fig.1 Free Radical Scavenging Activity of Different Extracts of Pisonia alba And Mukia maderaspatana

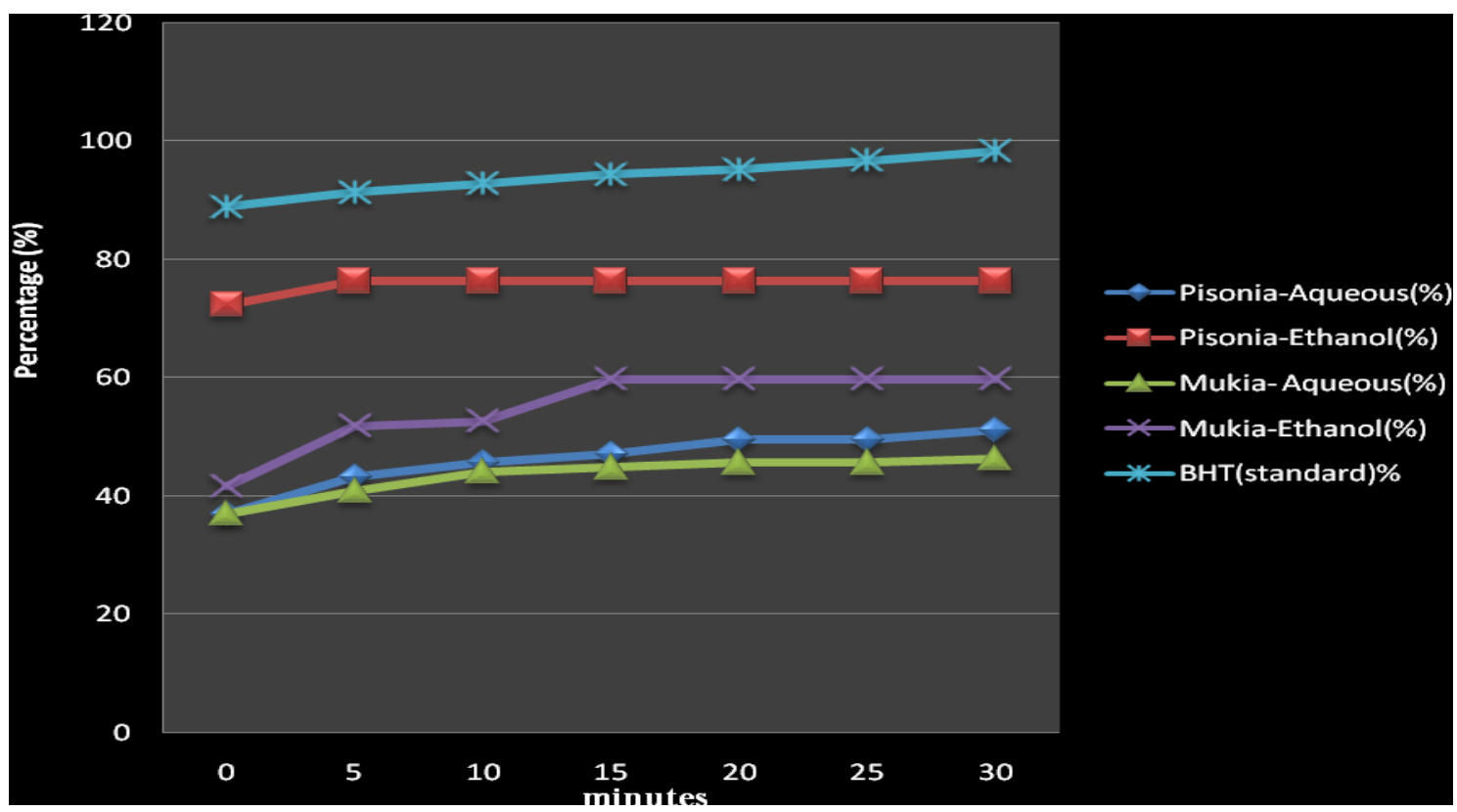


Fig.2 Comparative View of Inhibition of Zone Made by Ethanolic Extracts of Pisonia alba on Different Bacterial Strains

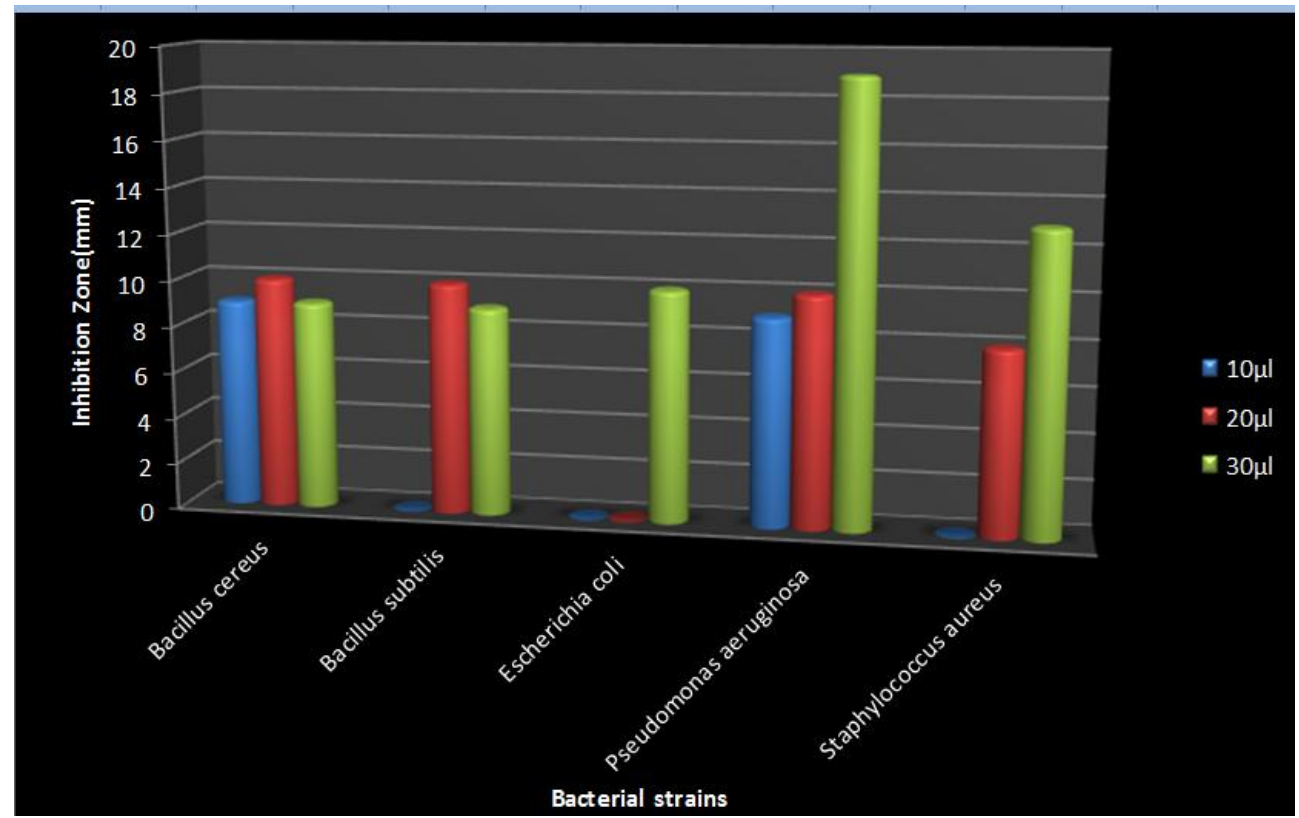

Fig.3 Comparative View of Inhibition of Zone Made by Ethanolic Extract of Mukia maderaspatana on Different Bacterial Strains

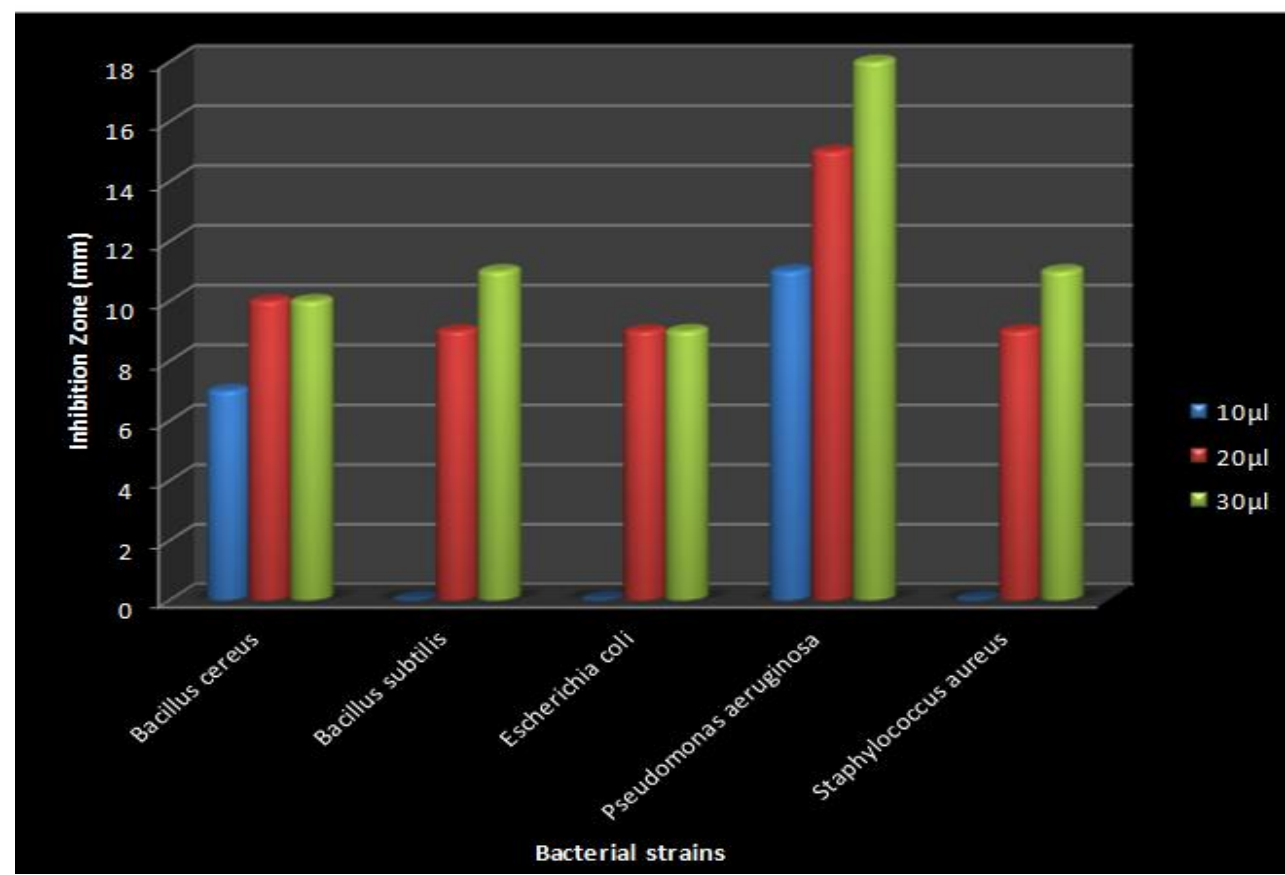

The Mukia maderaspatana leaves is most effective against Pseudomonas aeruginosa and Lachaikottei leaves is most effective against Bacillus cereus hence these plant 
extracts has great posses antimicrobial compounds. It can be used in the treatment of diseases caused by this pathogen by the discovery of drugs against this pathogen.

Earlier studies showed that the plants are the vital source of innumerable number of antimicrobial compounds. Several phytoconstituents like flavonoids (Tsuchiya et al., 1996), phenolics and polyphenols (Mason \& Wasserman, 1987), tannins (Ya et al., 1988), terpenoids (Scortichini \& Pia Rossi, 1991), sesquiterpenes (Goren et al., 1996) etc., are effective antimicrobial substances against a wide range of microorganisms. In this endeavour, traditional herbal medicines must perforce be granted the benefits of modern science and technology to serve further global needs.

\section{Acknowledgement}

The authors are grateful to the Principal and Management, JBAS College for women, Chennai, Tamilnadu, India for providing the necessary infrastructure to carry out this research work in a successful manner and extend their thanks to the Chief Scientist of Poonga Biotech Research centre for providing the facility to work in the lab.

\section{References}

Al-Bari, M.A.A., Sayeed, M.A., Rahman, M.S. 2006. Characterization and antimicrobial activities of extracts in a phenolic acid derivative produced by Streptomyces bangladeshiensis, a novel species collected in Bangladesh. Res. J. Med. Med. Sci., 1: 77-81.

Asl, M.N., Hosseinzadeh, H. 2008. Review of pharmacological effects of Glycyrrhiza sp. and its bioactive compounds. Phytotherapy Res., 22(6): 709-24.

Balakumar, S., Rajan, S., Thirunalasundari, T., Jeeva, S. 2011. Antifungal activity of Aegle marmelos(L) Correa (Rutaceae) leaf extract on dermatophytes. Asian Pacific J. Trop. Biomed., 1(4): 309-312.

Baravalia, Y., Kaneria, M., Vaghasiya, Y., Parekh, J. and Chanda, S. 2009. Antioxidant and antibacterial activity of Diospyros ebenum Roxb leaf extracts. Turkish. J. Biol., 33: 159-164.

Erturk, O., Kati, H., Yayli, N., Demurbau, Z. 2006. Antimicrobial Properties of Silene multifida (Adams) Rohrb. Plant Extracts. Turk. J. Biol., 30: 17-21.

George, H., Teng, C.M., Wu, C.L., Ko, F.N. 1996. Marchantin $\mathrm{H}$ as a natural antioxidant and free radical scavenger. Arch. Biochem. Biophys., 334: 18.

Gopalakrishnan sasi priya, Raghu radhika, Perumal siddhuraju. 2012. Antioxidant and Antimicrobial activity of traditional Indian leafy vegetables: Mukia maderaspatana and Solanum trilobatum. Int. J. Pharmacy and Pharmaceutical Sci., 4(2): 513-521.

Goren, N., Woerdenbag, H., BozokJohansson, C. 1996. Cytotoxic and antibacterial activities of sesquiterpene lactones isolated from Tanacetum praeteritum subsp. praeteritum. Planta Medica, 62: 419.

Halliwell, B., Gutteridge, J.M.C. 1992. Free radicals, antioxidants and human diseases: where are we now?. J. Lab. Clin. Med., 119: 598-620.

Iwu, M.W., Duncan, A.R., Okunji, C.O 1999. New antimicrobials of plants origin In: J.Janick (ed), Perspectives on new crops and new uses, ASHS Press. Alexandria VA: 457-462.

Janarthanam, B., Sumathi, E. 2010. Antimicrobial activity of Gymnema sylvestre leaf and callus extracts. $J$. Trop. Med. Plants 11(2): 143-147.

Kala, S., Johnson, M., Raj, I., Bosco, D., Jeeva, S., Janakiraman, N. 2011. Preliminary phytochemical analysis of 
some medicinal plants of South India. $J$. Natura Conscientia 2(5): 478-481.

Lee, S.E., Hwang, HJ.,. Ha, J.S. 2003. Screening of medicinal plant extracts for Antioxidant activity. Life Sci., 73: 167-179.

Lopez, A., Hudson, J.P., Towers, G.H.N. 2001. Antiviral and antimicrobial activities of Colombian medicinal plants. J. Enthopharmacol., 77: 189 196.

Mallikadevi, T., Paulsamy, S., Karthika, K. and Jamuna, S. 2012. Protocol for invitro culture from leaf and nodal explants of Mukia maderaspatana (L.) M.Roem.- an important traditional medicinal climber. J. Scientific res. Pharmacy, 1(3): 36-40.

Mason, T.L., Wasserman, B.P. 1987. Inactivation of red beet betaglucan synthase by native and oxidized phenolic compounds. Phytochemistry, 26: 2197.

Moumita banerjee, Thankamani, V. 2013. Antimicrobial activity of plant Mukia maderasatana. Int. J. Pharmacy and Pharmaceutical Sci., 7:199-202.

Natarajan, D., Shiva Kumar, M.S., Srinivasan, R. 2010. Antibacterial activity of leaf extracts of Biophytum sensitivum (L.) DC. J. Pharmacol. Sci. Res., 2(11): 717720.

Ozkan, G., Sagdic, O., Baydar, N.G., Baydar, H. 2004. Antioxidant and Antibacterial Activities of Rosa damascene Flower Extracts. Food Sci. Tech. Int., 10 (4): 277-281.

Padamanabhan vasanthi, Manimekalai Ganapathy, Evanjelene V.K., Nirmala Ayyavuv, Jagajothi Angamuthu. 2014. Phytochemical screening and antioxidant activity of extracts of the leaf and bark of Albizzia lebbeck (Benth). Academia J. Med. Plants, 2(2): 26-30.

Paulraj, K., Irudayaraj, V., Johnson, M.,
Patric, R.D. 2011. Phytochemical and antibacterial activity of epidermal glands extracts of Christella parasitica $(\mathrm{L}) \mathrm{H}$. Lev. Asian Pacific J. Trop. Biomed., 1(1): 8-11.

Peteros, N.P. 2010. Antioxidant \& cytotoxic activities \& phytochemical screening of four Phillppine medicinal plants. $J$. Med. Plant. Res 4(5): 407-414.

Prabu, D., Nappinnai, M., Ponnudurai, K. and Prabu, K. 2008. Evaluation of WoundHealing Potential of Pisonia grandis R.Br: A Preclinical study in Wister Rats. Int. J. Lower Extrem. Wounds, 7: 2 -7.

Radha, R., Arokiyaraj, S., Agastian, P., Balaraju, K., Mohan Kumar, R. and Balu, P. 2008. Phytochemical analysis and anti-inflammatory activity of Pisonia grandis R.Br. J. Biomed. Pharmacol., 1: 27.

Samundeeswari, A., Chittibabu, C.V. 2013. In-vitro antifungal activity of Naringi crenulata (Roxb.) Nicols leaf extract. Int. J. Curr. Sci., 5: 82-85.

Saritha, B., Karpagam, Sumathi. 2014. Studies on antioxidant activity, phenol and flavonoid content of Pisonia alba span. Asian J. Pharmaceutical And Cli. Res., 7: 106-109.

Savithramma, N., Lingarao, M., Suhrulatha, D. 2011. Screening of medicinal plant for secondary metabolites. Middle-East J. Sci. Res., 8: 579-584.

Scortichini, M., Pia Rossi, M. 1991. Preliminary in-vitro evaluation of the antimicrobial activity of terpenes and terpenoids towards Erwinia amylovora(Burrill) Winslow et al., $J$. Appl. Bacteriol., 7: 109.

Selvaraj, S., Chittibabu, C.V., Janarthanam, B. 2014. Studies on phytochemical screening, antioxidant activity and extraction of active compound (swertiamarin) from leaf extract of Enicostemma littorale. Asian J. 
Pharmaceutical Clin. Res., 7(4): 240244.

Shah, G.L., Gopal, G.V. 1986. Folk-lore medicines of Vasavas, Gujarat, India. Ac Bot Ind., 14: 48-53.

Shubashini, K., Sripathi and Poongothai, G. 2010. Bioassay- guided fractionation and antifungal activity studies on Pisonia grandis R. Br. Int. J. Curr. Res., 10: 35-37.

Sies, H., Stahl, W., Sundquist, A.R. 1992. Anti-Oxidant function of vitamins, E \& C, Beta-Carotene, other Cartenoids. Annuals of New York, Acad. Sci., 669: 7-20.

Singh, M.R., Panda, H. 2005. Medicinal herbs with their formulations. Daya Publishing House: 547.

Sowndhararajan, K., Jince Mary Joseph, Rajendrakumaran, D., Manian, S. 2010. In vitro antioxidant characteristics of different parts of Melothria maderaspatna (L.). COGN. Int. J. Pharmacy And Pharmaceutical Sci., 2(3): 117-123.
Sunil, P., Latha, G., Suja, S.R., Shine, V.J. and Shyamal, S. 2009. Effect of ethanolic extract of Pisonia alba span.Leaves on blood glucose levels and histological changes in tissues of alloxan-induces diabetic rats. Int. J. Applied Res. Nat. Prod., 2: 11

Tsuchiya, H., Sato, M., Miyazaki, T., Fujiwara, S., Tanigaki, S. et al. 1996. Comparative study on the antibacterial activity of phytochemical flavanones against methicilian-resistant Staphylococcus saureus. J. Ethnopharmacol., 50: 27.

Xu, R., Zhao, W., Xu, J., Shao, B., Qin, G. 1996. "Studies on bioactive saponins from Chinese medicinal plants". $A d v$. Experimental Med. Biol., 404: 371-82.

Ya, C., Gaffney, S.H., Lilley, T.H., Haslam, E. 1988. Chemistry and significance of condensed tannins. Hemingway RW, Karchesy JJ, ed. In plenum press, New York 553.

\section{How to cite this article:}

Vishnupriya, C., and Fauzia ahmed. 2017. Potency of Two Commonly Available Plants Pisonia alba and Mukia maderaspatana in the Health Industry. Int.J.Curr.Microbiol.App.Sci. 6(1): 721-732. doi: http://dx.doi.org/10.20546/ijcmas.2017.601.086 